\title{
Factors Affecting Information Technology Audit Quality
}

\author{
Yahya Hasas Yeghaneh ${ }^{1}$, Mostafa Zangiabadi ${ }^{2,}$, , Seyed Mostafa Dehghani Firozabadi ${ }^{3}$ \\ ${ }^{1}$ Scientific Group of Accounting, Department of Allameh Tabataba'i University, Tehran, Iran \\ ${ }^{2}$ Faculty of Accounting, Allame Tabatabaee University, Tehran, Iran \\ ${ }^{3}$ Faculty of Accounting, Islamic Azad University, Yazd, Iran
}

\section{Email address:}

Yahya_yeghaneh@yahoo.com (Y. H. Yeghaneh),m.zangiabadi229@gmail.com (M. Zangiabadi), dehghani_firozabadi20@yahoo.com (S. M. D. Firozabadi)

\section{To cite this article:}

Yahya Hasas Yeghaneh, Mostafa Zangiabadi, Seyed Mostafa Dehghani Firozabadi. Factors Affecting Information Technology Audit Quality. Journal of Investment and Management. Vol. 4, No. 5, 2015, pp. 196-203. doi: 10.11648/j.jim.20150405.19

\begin{abstract}
Change and the growth of information technology, all aspects of human society have taken in the light of self. Human need, interest in using new technologies emerged as a dominant factor in their organizations and they will force to keep pace with the condition. Since the major factor in advances in information technology in the present world, is the need and necessity. This important, changed the methods and practices and have been transformed of paper-based systems to electronic information systems and software. Accounting and auditing profession, perhaps more than in other areas of financial knowledge have been disposable of Enjoyment and use of the facility is subject to the new environment. New environment recording and reporting of information, has created much effects in the efficiency and effectiveness of the auditing profession And the need to use information technology audit to be felt more than ever. Therefore, in this study, are followed to find the factors affecting on information technology audit quality. In order to, Standard questionnaire was used that test its validity before and also reliability $89 \%$ was measured. And results show that from the view of CPAs working in the audit institute and the audit organization, properly accountability of audit team and existence audit framework and process, business criteria and audit scope, auditability, planning and operations, access to resources, relationship with the entity and the business environment, affects IT audit quality.
\end{abstract}

Keywords: Audit, ITS Audit, Audit Quality

\section{Introduction}

The spread of information technology and the need for rapid access to detailed, relevant and timely, with minimum cost and maximum efficiency, Interest in using new technologies proposed as a dominant factor organizations and forcing them to keep pace with the condition. Need and necessity is main factor developments and technology in today's world, the need and necessity. This new wave and fast, have changed method of doing things, and the have been change from paper-based systems to electronic information systems and software. Accounting and auditing profession, perhaps more than other areas of financial knowledge, is exposed to enjoy resources of the new environment. New space for recording and reporting of information, many effects in efficiency and effectiveness of this practice has caused [34].

Thus, IT auditing, is one of the aspects of advances in technology in accounting and auditing, can be interpreted in two ways:

1. IT audit, that, The purpose of that, audit accounting information systems and other technologies that are used to collect accounting data as a manifestation of information technology.

2. IT audit, that can know to be used type of Audit software and use computer-based tools for auditing and auditors help. The second is to reduce Iran. Today, efforts to do this important work are in progress. It is hoped that this research addresses this issue, it's important to be able to solve and help this issue.

On the other hand, quality is determinant of audit function is a function of several factors such as: audit capabilities (including knowledge, experience, ability to adapt and technical efficiency) and professional performance (including independence, objectivity, professional care, conflict of interest and judgment). Structure of Audit quality is a multidimensional, but invisible, so it is very difficult to measure the quality, since many factors affect audit quality. The determination framework for identifying audit quality is the important issue [38].

Investigation Effect of audit quality of audit perspective 
(supplier of services) is an important issue. In this study examines auditors' views on the impact of factors affecting IT audit quality, factors such as proper accountability audit team, the audit framework and procedures, business criteria and audit scope, auditability, planning and operations, access to resources, relationship with the entity and the business environment, as research independent variables and audit quality IT as a dependent variable to measure the effect of these factors on audit quality. The present study sought to appropriate and scientifically answer to the question, that, whether The factors expressed above, the influence of information technology audit quality or not?

\section{The Theoretical Basis and Background of Research}

\subsection{Information Technology Audit}

When auditing the desired computer environments, the overall objectives and scope of audit work does not change, but the audit procedures, the auditor may need to consider the use of computers and information technology, One of the basic definitions of computer audit, is Williamson's definition which according to that, of IT (Computer)audit, the proses of application any system based on of information technology in order to assist auditors in the process of planning, implementation, monitoring, and conducting audit procedures are completed [18]. The use of computer audit has great benefit such as improvement of quality and auditor's judgment increasing efficiency and reducing cost of auditing and improving in a competitive situation. Given the above, IT audit is the process that Using the same steps and repeat the running time and place, and in the organizations with different workplace and organizational goals are employed [27].

\subsection{Important Factors Affecting Audit Quality}

Conceptual standpoint, there are three fundamental aspects of audit quality include inputs, outputs and the underlying factors. There is a lot input about audit quality separate from standard. For example, one of the most important personal characteristics auditors is the skill and experience of the auditor, the ethical values and way of thinking. Another important input is the audit process. Audit process refers to such as properly audit procedure, effectiveness of audit tools and convenient access to support technics. All of these cases are involved in audit quality. In addition, the audit outcomes also have a significant impact on audit quality because most stakeholders in their assessment of audit quality outcomes audit report are being addressed [45].

\subsection{Audit Quality}

Audit quality is defined in different ways. In Applied Literature, audit quality is often defined by the extent of their compliance with auditing standards. In contrast, researchers in accounting and auditing, have been addressed multiple dimensions of audit quality dimensions, this dimensions is often different definitions. Some of the most common definitions of audit quality include: market assessment of the likelihood that the financial statements contain material misstatement, and the auditor shall report the discovery of misstatement [13] likelihood that auditor into the financial statements is likely to contain material misstatement has issued unqualified reports fails Palmerose (1988)[43] defines audit quality in terms of the degree is accredited auditor. Since the purpose of the audit, make sure into financial statements, so, audit quality means financial statements audited being free from material misstatement. In fact, this definition emphasizes the results of the audit, the audited financial statements of reliable, and reflects high quality audit. This definition leads to the following question: "How are users to evaluate the amount of reliable the audited financial statement?" This definition of audit quality is based on the quality of audits conducted, since the reliability level of audited financial statement cannot be determined before play audit. Consequently, the Palmerose definition focuses on real audit quality. Titman and Trueman (1986)[52]. the audit quality is accuracy level of the information that is available to investors have been defined. This definition is similar to the Palmerose definition of audit quality. Davidson and Neu (1993) [15] defines audit quality, auditor's ability to detect and report material misstatement of net income.

\subsection{Prior Related Literature}

Previous IT audit studies have focused primarily on specific aspects or characteristics of IT audit or assurance tasks. For example, recently authors have explored the IT proficiency of auditors and the importance of IT knowledge for assurance practitioners as one critical component of IT auditing $[5,20$, $54,33,4$, and 10]. Researchers have also used case studies of IT audits to identify potential concerns and improvement opportunities for IT audit [48]. Additionally, researchers have explored the potential impact of group dynamics and group support systems [5, 40, and 41]. Additional research related to IT audit has investigated the impact that IT has on financial audit, internal controls, or other projects. Examples include work that investigates the changing role of IS audit and auditors in US accounting firms [3, 42]; the effect of internal control reliability on IT audit hours and fees [12]; the effect of IT on auditor detection of misstatements [36] and the general implementation of technology for auditing [16, 10, 17].

Recent work by Merhout and Havelka toward developing a theory for the IT audit process utilized group data gathering techniques with IT audit practitioners, internal and external, to create a framework of logical factors related to IT audit quality. They identified a large (over 260) set of attributes (referred to as factors by Merhout and Havelka) that were suggested by practitioners as "critical" to the IT audit process. While they logically categorize the attributes identified, Merhout and Havelka do not provide any empirical evidence to support their framework or to evaluate the importance of the attributes or the categories they suggest [22, 37,24].

There are two primary works which review the literature 
and identify measurable attributes:

First, Schroeder, Solomon and Vickrey (1986) surveyed audit committee chairs and audit partners on 15 specific "factors" of audit quality from prior research and identified eight of these as having a strong or very strong impact on audit quality, including executive involvement, planning/conduct field work, communication to management, independence, technical competence, team experience, quality control, and communication to audit committee [47].

Second, the approach of Carcello et al. (1992) extended Schroeder et al. in that they developed a broader survey of audit quality attributes and administered the survey to a combination of external audit, internal audit, and business professionals. Using a factor analysis technique, Carcello et al. identified 12 factors overall, including four primary factors: client experience, industry experience, responsiveness to client needs, and compliance with GAAS [6].

An alternative approach used to identify audit quality factors is through direct solicitation from audit professionals using interviews and group-based approaches. The primary work in this area is by Sutton and Lampe, One of the unique benefits of this approach is the potential detail and rich data set developed. These studies identified 19 specific attributes. Examples of the attributes identified by Sutton and Lampe's studies include audit team expertise, audit timing requirements, audit manager involvement, and prior notes and work papers [50, 51, and 31].

Catanach \& walker (1999) introduced a model that illustrates the audit quality is functions of two main audit quality factors related to audit performance. These factors include: the abilities of the auditor (including knowledge, experience, ability to adapt and technical efficiency) and professional (including independence, objectivity, professional care, conflict of interest and judgment). In addition to the performance features, their model includes the effect of economic incentives (such fee, costs, performance, legal claims and consulting services), market structure (including competition, industry concentration and economies in scale) and audit mechanisms, legislation and employment status [8].

On the other hand of 1981 to now, several studies conducted in other countries in the field of audit quality, a fundamental problem in audit quality definition is differentiation between audit quality and auditor quality. Audit quality is simply not possible to measure and the actual quality of audit is invisible and it can only be assessed after performing audits, Palmrrose For example, in 1988, to measure actual quality is used the amount of lawsuits against auditors [21].

Persso \& svanstrom (2011) in his thesis entitled Factors affecting audit quality; studies have indicated that the mission of the auditor and the auditor's age, does not matter in audit quality [44].

Zureigat (2011) in a research entitled the impact of ownership structure on audit quality after studies have concluded result show that There is a relation between audit quality and construction companies by institutional ownership or foreign ownership are governed, and ownership concentration have a negatively non-significant relation with audit quality and also institutional and foreign owners are willing to hire high-quality auditors[56].

Makni \& et al.(2012) in study entitled the impact of corporate governance mechanisms on audit quality after studies showed that the size of the board, the separation of the chairman of the board, CEO, percentage of the majority owners have a positive impact on the demand for high-quality audit and percentage of the Institutional investors and size of the entity have a negative effect on the demand for audit quality. also existane non-duty members of the board, chairman of the board and the amount owed by the entity has no effect on the selection of quality auditors[35].

Stoel et al.(2012)in study began examines the factors influencing the quality of IT audit, after studies and using questionnaires that distributed among accountants, auditors and IT Audit Creators (accounting software), the factors such as, independed, Having knowledge of accounting and auditing skills, knowledge of business processes, accountability, audit frameworks and procedures, business standards and scope of the audit, auditability, audit experience than the entity's IT awareness and control, planning and operations, access to resources associated with the entity and the business environment as factors affecting audit quality IT identified[49].

Merhout \& Havelha (2013) in a study whit titled internal IT audit process quality, were located 26 aspect of internal IT audit quality in 6 Floor, Audit organization, Corporate entity environment, process and procedure, system or objectives process and Audit staff[23] langari (2002) scale of measure the actual quality factor has considered compliance of fifteen audit quality control in audits Audit organization[32].

Mojtahedzade and aghaei (2004) in a thesis entitled "Factors affecting the visual quality independent audit by independent auditors and users", using the auditing literature, accepted auditing standards, statements and terms of environmental, factors affecting Quality audit be identified. The study population consisted of two groups of users of audit services, including management (senior experts) investment companies and executives (senior experts) credit department and independent auditors, including auditing partners, senior managers and technical managers of the audit. The findings of the study indicate that factors such as tenure, industry expertise, complete audit on time budget, employer reputation, audit fee, audit managers and partners to monitor the quality of the audit work performed influence on the independent audit[38].

Jafari (2006) investigated the factors affecting the audit quality auditors paid member of certified public accountants audit. He with gathering questionnaire data and test His hypothesis show that a meaningful relationship among the factors affecting the competence of auditors and auditor independence and audit quality. Secondly investigator with documents, audit reports and 167 nomber of stock company financial statements between 2001 till 2003 concluded that formal audits of auditor and report the discovery of a material misstatement of the financial statements is not 
effectiveness [26].

Zangiabadi (2014) in his dissertation examines the factors influencing the quality of IT audit began after studies and using questionnaires that distributed between CPAs practitioner in audit organization and auditing institute, And results show that from the view of CPAs working in the audit and the audit, independence, knowledge and skills in accounting, auditing, business process knowledge, properly accountability of audit team and the audit process, audit criteria and scope of business, auditability, audit experience to the entity's IT awareness and control, planning and operations, access to resources associated with the entity and the business environment, affects IT audit quality[55].

\section{Research Hypotheses}

These assumptions of this study According to discussion are provided in previous sections as follows:

First hypothesis: proper accountability audit team members are affected on IT audit quality.

Second hypothesis: the existence of proper framework and audit procedures is affected on IT audit quality.

Third hypothesis: business criteria and audit scope is affected on IT audit quality.

Fourth hypothesis: the auditability of entity is affected on IT audit quality.

Hypothesis V: Planning and implementing effective audit is affected on IT audit quality.

Hypothesis VI: Access to entity resource is affected on IT audit quality.

Hypothesis VII: associated with entity is affected on IT audit quality.

Hypothesis VIII: business environment is affected on IT audit quality.

\section{Methodology}

This research is applied studies in terms of purpose. Applied research is research that are developed theories, regulation, principles and techniques that in basic research and applies to solve real and executive problems. And this research is causal- descriptive in the nature and content. In other words, this study analyzes the now status and to describe the current situation regularly and systematically and examines the characteristics and attributes and necessary to examines the relationship between the variables. Casual studies are applied studies in terms of purpose and their results usually are used to prevent the recurrence of adverse events, and development of appropriate events [28].

\subsection{Data Collection Methods}

There are several methods of data collection. In a study may be used of several methods to collect information. In this study are used of literature methods to literature review, in this method was studied literature and sources used in the research of their products. It also examines the views of CPAs are used of standard questionnaire with a Likert five options that have the validity previously been used to test and its reliability is 89 percent. Into analysis obtained data are used of descriptive statistics and inferential statistics. Data analysis After collecting and organizing data, that valuation is based on the Likert scale and tests has been done to determine the T-Student, the data transfer to a PC using, SPSS and Minitab.

\subsection{Research Community}

The first step in sampling is to define the target population. The participants in the study or in the other hand, statistical community, is CPAs working in the auditing organization and auditing institute, argument of choose CPAs into statistical population is they having a long professional experience, college education, and most importantly, it is possible for auditors to used audit software in audit process.

\subsection{Research Sample}

In the present study, non-probability purposive sampling method are used to distribute questionnaires and have been trying representative sample of the community. The sample size is calculated from formula kokran as follows [28]:

$$
n=\frac{N z_{\alpha / 2}^{2} p Q}{N d^{2}+z_{\alpha / 2}^{2} p Q}
$$

In this formula $\mathrm{N}$ is the population size and $\mathrm{n}$ is the sample size in each sector.

Other components of the formula are as follows:

$\mathrm{d}$ : absolute error is equal to 0.1 is considered.

$\mathrm{p}$ : ratio of 0.5 is considered to be the maximum size.

$\mathrm{q}=1-\mathrm{p}$ : Here's a 0.5 .

$z_{\alpha / 2}$ : Percentile $(1-\alpha / 2) * 100$ of the standard normal distribution where the $96 / 1$ is the ninety-fifth percentile of the standard normal distribution.

According to the above formula the sample size of 89 patients for auditors which is calculated as follows:

$$
n=\frac{1255 \times(1 / 96)^{2} \times 0 / 25}{1255 \times(0 / 1)^{2}+(1 / 96)^{2} \times 0 / 25} \approx 89
$$

\section{Research Findings}

First hypothesis: proper accountability of audit team members is affected on IT audit quality.

In follow-up hypotheses testing looking into explaining the effect proper accountability of audit team members on IT audit quality. T-statistics of the hypothesis is equal to -5.708 and a significance level equal to 0.000 , which indicates that the null hypothesis i.e. no effect proper accountability of audit team members on IT audit quality rejected and can be adopted against hypotheses That show, proper accountability of audit team members is affecting on IT audit quality. 
Table 1. T- Student For the first hypothesis.

\begin{tabular}{llll}
\hline Mean & Standard deviation & $\mathbf{t}$ & Sig \\
\hline 2.000 & 0.6784 & -10.927 & 0.000 \\
\hline
\end{tabular}

Second hypothesis: existence of proper framework and audit procedures is affected on IT audit quality.

In follow-up hypotheses testing looking into explaining the effect existence of proper framework and audit procedures on IT audit quality. T-statistics of the hypothesis is equal to -14.43 and a significance level equal to 0.000 . Which indicates the null hypothesis, i.e. there is no effect existence of proper framework and audit procedures on IT audit quality, rejected and can be adopted against hypotheses that show, existence of proper framework and audit procedures on IT audit quality.

Table 2. T-Student For the second hypothesis.

\begin{tabular}{llll}
\hline Mean & Standard deviation & t & Sig \\
\hline 1.9 & 0.4706 & -14.43 & 0.000 \\
\hline
\end{tabular}

Third hypothesis: framework and audit procedure is affected on IT audit quality.

In follow-up hypotheses testing looking into explaining the framework and audit procedure on IT audit quality. T-statistics of the hypothesis is equal to -4.06 and a significance level equal to 0.000 , which indicates that the null hypothesis i.e. no effect framework and audit procedure on IT audit quality, rejected and can be adopted against hypotheses That show, framework and audit procedure is affected on IT audit quality.

Table 3. T-Student For the third hypothesis.

\begin{tabular}{llll}
\hline Mean & Standard deviation & t & Sig \\
\hline 2.6 & 0.7838 & -4.06 & 0.000 \\
\hline
\end{tabular}

Fourth hypothesis: the auditability of entity is affected on IT audit quality.

In follow-up hypotheses testing looking into explaining the effect the auditability of entity on IT audit quality. T-statistics of the hypothesis is equal to -14.39 and a significance level equal to 0.000 , which indicates that the null hypothesis i.e. no effect the auditability of entity on IT audit quality, rejected and can be adopted against hypotheses That show, the auditability of entity is affected on IT audit quality.

Table 4. $T$ - Student For the fourth hypothesis.

\begin{tabular}{llll}
\hline Mean & Standard deviation & t & Sig \\
\hline 1.768 & 0.5936 & -14.39 & 0.000 \\
\hline
\end{tabular}

Fifth Hypothesis: Planning and implementing effective audit is affected on IT audit quality.

In follow-up hypotheses testing looking into explaining the Planning and implementing effective audit on IT audit quality. T-statistics of the hypothesis is equal to -14.46 and a significance level equal to 0.000 , which indicates that the null hypothesis i.e. no effect Planning and implementing effective audit on IT audit quality, rejected and can be adopted against hypotheses That show, Planning and implementing effective audit is affected on IT audit quality.

Sixth Hypothesis: Access to entity resource is affected on IT audit quality.

In follow-up hypotheses testing looking into explaining the effect Access to entity resource on IT audit quality. T-statistics of the hypothesis is equal to -5.708 and a significance level equal to 0.000 , which indicates that the null hypothesis i.e. no effect : Access to entity resource is affected on IT audit quality, rejected and can be adopted against hypotheses That show, Access to entity resource is affected on IT audit quality.

Table 5. $T$ - Student For the fifth hypothesis.

\begin{tabular}{llll}
\hline Mean & Standard deviation & t & Sig \\
\hline 1.96 & 0.4188 & -14.46 & 0.000 \\
\hline
\end{tabular}

Table 6. $T$ - Student For the sixth hypothesis.

\begin{tabular}{llll}
\hline Mean & Standard deviation & t & Sig \\
\hline 2.02 & 0.6481 & -10.95 & 0.000 \\
\hline
\end{tabular}

Seventh Hypothesis: communication with entity is affected on IT audit quality.

In follow-up hypotheses testing looking into explaining the effect communication with entity on IT audit quality. T-statistics of the hypothesis is equal to -13.68 and a significance level equal to 0.000 , which indicates that the null hypothesis i.e. no effect communication with entity on IT audit quality, rejected and can be adopted against hypotheses That show, communication with entity is affected on IT audit quality.

Table 7. T-Student For the seventh hypothesis.

\begin{tabular}{llll}
\hline Mean & Standard deviation & t & Sig \\
\hline 1.93 & .4952 & -13.68 & 0.000 \\
\hline
\end{tabular}

Eighth Hypothesis: business environment is affected on IT audit quality.

In follow-up hypotheses testing looking into explaining the effect business environment on IT audit quality. T-statistics of the hypothesis is equal to -10.74 and a significance level equal to 0.000 , which indicates that the null hypothesis i.e. no effect business environment on IT audit quality, rejected and can be adopted against hypotheses That show, business environment is affected on IT audit quality.

Table 8. T- Student For the eighth hypothesis.

\begin{tabular}{llll}
\hline Mean & Standard deviation & t & Sig \\
\hline 1.9 & .48917 & -10.74 & 0.000 \\
\hline
\end{tabular}

\section{Discussion and Conclusions}

Growth of information technology has taken Beam in all aspects of human society.

Human need, interest in using new technologies emerged as a dominant factor organizations and has forcing them to keep 
pace with the condition. Because the need and necessity is the main factor in the development of information technology in today's world, this important, techniques and ways of doing things have changed and have been change from paper-based systems to electronic information systems and software. Accounting and auditing profession, perhaps more than other areas of financial knowledge and resources to enjoy the new environment and at risk. New space for recording and reporting of information has created much of the efficiency and effectiveness of this practice. And requires the use of IT audit is felt more than ever. Therefore, in this study, are followed to explore the factors affecting information technology audit quality. According to the first hypothesis, responding to the needs of the entity's audit team and work with it and complete the audit process in management framework, which creates a desire for better auditing. Results this hypothesis with other studies, such as research Carcello et. al 1992; Behn et al 1997, Chen et al 2001; Samelson et al2006; Schroeder et. Al, 1986 and Stoel et al, 2012 are aligned. According to the second hypothesis, methods, procedures, forms and other tools and complete audit can assist auditors in performing quality audit work. The results of this research hypothesis with other studies, such as research, Carcello et. al 1992; Samelson et al, 2006; Behn, et al, 1997; O'Donnell et al 2000; Stoel et al.2012, are aligned. According to the third hypothesis, considering the criteria of any business entity and determine the audit scope properly to carry out helps audit work to performed quality. The results of the research hypothesis with other studies, such as research, Carcello et. al 1992; behn, et al, 1997; Schroeder,\& et. Al, 1986 and Stoel et al.2012 are aligned. The fourth hypothesis suggests that, according to the auditability of the audited entity before accepting the job can be done in an audit work quality and be effective. The results of this research hypothesis with other studies, such as research, Carcello et. al 1992; behn, et al, 1997; Schroeder et. Al, 1986 and Stoel et al.2012 are aligned. The fifth hypothesis suggests that to perform any work must have an accurate budgeting and accomplishment audit operating favorably. The results of the research hypothesis with other studies, such as research, Carcello et. al 1992; behn, et al, 1997; Schroeder et. al, 1986 and Stoel et al, 2012 are aligned. The sixth hypothesis suggests that auditors should accept and perform the audit to quality should consider available to entity reliable resources, the results of this hypothesis with other studies, such as research, Carcello et. al 1992; behn, et al, 1997; Schroeder,\& et. Al, 1986 and Stoel et al, 2012 are aligned. The seventh hypothesis suggests that have a communication with audited entity case to better recognition auditor into condition and character of that entity and auditors can be detection misstatement in financial statement and enjoyment her performance of high quality. The results of the research hypothesis with other studies, such as research, Carcello et. al 1992; behn, et al, 1997; Schroeder et. al, 1986. Stoel et al.2012; mojtahedzadeh and aghaei, 1383, is aligned. The eighth hypothesis suggests that one of factors affecting on IT audit quality, is business environment, entity activities and risks, which can be to mystification for auditors in condition auditors haven't enough know. But in condition that auditors have sufficient knowledge, it may be help the entity's auditors in order to improvement the quality of audit work. The results of the research hypothesis with other studies, such as research, Carcello et. al 1992; behn, et al, 1997; Schroeder et. Al, 1986 and Stoel et al, 2012 are aligned.

\section{References}

[1] Azar. A. \& Momeni, M. (1379). Statistics and its Application in Management, Tehran: Publication of the first volume.

[2] Behn B, Carcello J, Hermanson DR, Hermanson RH. The determinants of audit client satisfaction among clients of big 6 firms. AccHoriz 1997; 11:7-24.

[3] Bagranoff N.A, Vendrzy k.VP. "The changing role of IS audit among the big five US-based accounting firms". InfoSyst Cont J 2000; 5 .

[4] Brazel J. "A measure of perceived auditor ERP systems expertise". Managerial Aud J2005; 20(6):619-31. acarnaghan C." Discussion of it assurance competencies" .Int J Acc Info Syst2004; 5: 267-273.

[5] Carcello J, Hermanson R, McGrath N." Audit quality attributes: the perceptions of audit partners, preparers, and financial statement Users". Aud J Pract Theory 1992; 11: 1-15.

[6] Carcello J.V. and Nagy A.L (2004),"Audit Firm Tenure and Fraudulent Financial Reporting". Auditing: A Journal of practice \& Theory, Vol. 23, Issue 2, pp. 55-69.

[7] Catanach, a.h.jr. and p.l. walker(1999), "the international debate over mandatory auditor rotation: a conceptual research framework", journal of international accounting, auditing \& taxation, vol 8, pp 43-66.

[8] Chen CJP, Shome A, Su X. How is audit quality perceived by big 5 and local auditors in China? A preliminary investigation. Int J Aud 2001; 5: 157-75.

[9] Curtis M.B, Jenkins J.G, Bedard J.C, Deis D.R. "Auditors' training and proficiency in information systems: a research synthesis". IntJAccInfoSyst2009; 9: 104-121.

[10] Curtis M.B, Payne E.A. "An examination of contextual factors and individual characteristics affecting technology implementation deci-Sions in auditing" v. IntJ AccInf Syst 2008; 9: 104-21.

[11] Daigle R.J, Kizirian T, Sneathen L.D.J. "Systems controls reliability and assessment effort".IntJ Aud 2005; 9: 79-90.

[12] DeAngelo, L. E. (1981). "Auditor Size and Audit Quality", Journal of Accounting and Economics, Vol. 3, No. 3, 183-199.

[13] DeAngelo, L. (1981). "Auditor independence, "Low Balling," and disclosure regulation". Journal of Accounting \& Economics (August), pp. 113-127.

[14] Davidson, R.A. and D. Neu. (1993)"A note on Association between audit Firm size and audit Quality". Contemporary Accounting Research. Vol. 9, pp 479-488.

[15] Dowling C, Leech S. "Audit support systems and decision aids: current practice and opportunities for future research". Int JAcc InfoSyst 2007; 8: 92-116. 
[16] Dowling C. "Discussion of "An examination of contextual factors an dindividual characteristic saffecting technology implementation decisions in auditing". IntJAccInfoSyst 2008; 9: $122-126$

[17] For ghandost haghighi, K., (1999), " Computerizing Audit: quality or appearance", Journal auditor, numbers 4 and 5.

[18] Gartner Group. "Gartner says worldwide it spending to grow 5.1 percent in 2011". http://www.gartner.com/ it/page.jsp?id=1513614.

[19] Greenstein M, Mckee T.E. "Assurance practitioners and educators' self-perceived it knowledge level: an empirical assessment". IntJAccInfoSyst2004; 5: 213-43.

[20] Hsas yeganeh, Y. (2005), "Philosophy of Auditing", Scientific and Cultural Publications.

[21] Havelka D, Merhout J.A. "Grounded theory of the information technology audit process by external auditor: using group data for Grounded theory development". 1stAnnualPre CISW or kshopon Accounting Information Systems. Phoenix, AZ; 2009.

[22] Havelka, D. Merhout, J. W. (2013), " Internal information technology audit process quality: Theory development using structured group processes", International Journal of Accounting Information Systems, http://dx.doi.org/10.1016/j.accinf.2012.12.001

[23] Havelka D, Merhout J. "Development of an information technology audit process quality framework". AmConferInfoSyst 2007; 13: 1-7.

[24] Hun-Tong T, Kao A. Accountability effects on auditors' performance: the influence of knowledge, problem-solving ability, and task complexity. J Acc Res 1999; 37: 209-23.

[25] Jafari, A. (2006), "Factors influencing the independence and competence of the members of certified public accountants in providing certification services", Ph.D. Dissertation, University of Allameh Tabatabai.

[26] Kearney, B. and Tryfonas T. Security Patterns for Automated Continuous Auditing, Information Security Journal, 2008.

[27] Khalili Shorini, S. (2009), "Research methods in the social sciences", Tehran, Memorial Book, First Edition.

[28] Kinney, W. R. Jr. Z.-V. Palmrose, and S. Scholtz. (2004). Auditor independence, non-audit services, and restatements: Was the U.S. government right? Journal of Accounting Research 42 (3): 561-588.

[29] Knapp M. Factors that audit committee members use as surrogates for audit quality. Aud J Pract Theory 1991; 10: $35-52$.

[30] Lampe J.C, Sutton S. G. "Evaluating the work of internal audit:a comparison of standards and empirical evidence". AccBusRes 1994; 24: 14.

[31] Langari, M. (2002), "Factors influencing the independence and competence of auditors", Journal of Accounting Research, No. 10, Tehran, 61-69.

[32] Leader B." Discussion of it assurance competencies". IntJAccInfoSyst 2004; 5: 275-9.

[33] Mahdavi, GH. \& Mansouri Sh. (2012), "Information Technology and its impact on improving audit quality", auditor, No. $51,82-89$
[34] Makni, L., Kolsi, M.ch. and Affes, h, (2012), "The Impact of Corporate overnance Mechanisms on Audit Quality: Evidence from Tunisia", University of Sfax, Tunisia.

[35] Messier WFJ, Eilifsen A, Austen LA. Auditor detected misstatements and the effect of information technology. Int $\mathrm{J}$ Aud 2004; 8: 223-35.

[36] Merhout J, Havelka D. "Information technology auditing: avalue-added it governance partnership between it management and Audit". Comm Assoc InfoSyst 2008; 23: 463-483.

[37] Mojtahedzade, V. and aghaei, P. (2004), "Factors affecting audit quality independent auditors and users perspective", Journal of Accounting and Auditing, Volume 38, Tehran University School of Management.

[38] Momeni, M. (2010) "Data Analysis Using SPSS", Tehran, Frshyvh, Third Edition.

[39] O'Donnell E, Arnold V, Sutton SG. An analysis of the group dynamics surrounding internal control assessment in information systems audit and assurance domains. J Info Syst 2000a; 14: 97.

[40] O'Donnell E, Arnold V, Sutton SG. Reply to discussions of an analysis of the group dynamics surrounding internal control assessment in information systems audit and assurance domains. J Info Syst 2000b; 14: 5.

[41] Omoteso K, Patel A, Scott P. "Information and communications technology and auditng: current implications and future directions". IntJAud2010; 14: 147-62.

[42] Palmerose, Z. (1988)"An Analysis of Auditor litigation and Audit serviceQual ity. The Accounting review.Vol.64, pp. 55-73.

[43] Persso, U. \& svanstrom, T., (2011),"factors affecting audit quality", umea school business, spring September 2011.

[44] Rahmani, H. and Godarzi fekri, R. (2012), "Quality Audit", the International Accounting Standards Board to ensure system and (IAASB) of the International Federation of Accountants, (IFAC), Journal of Accounting.

[45] Samelson D, Lowensohn S, Johnson L. The determinants of perceived audit quality and auditee satisfaction in local government. J Public Budg Acc Finan Manage 2006; 18: 139-66.

[46] Schroeder M, Solomon I, Vickrey D. "Audit quality: the perceptions of audit audit-committee chairpersons and audit partners". Aud J Pract Theory 1986; 5: 86-94.

[47] Smith G.I.T. "greatest audit and security risks of 2006". JCorpAccFinan 2007; 18: 43-8.

[48] Stoel, D. \& Havelka, D. \& Merhout, W.J. (2012)" Ananalysis of attributes that impact information technology audit quality: A study of it and financial aud it pract itioners", International Journal of Accounting Information Systems, 13, 60-79.

[49] Sutton S.G, Lampe J.C."A framework for evaluating process quality for audit engagements" AccBusRes 1991; 21: 14.

[50] Sutton S.G. "Toward an understanding of the factors affecting audit quality" DecisSci1993; 24: 18. 
[51] Titman, S. and B. Trueman, (1986) "Information Quality and the Valuation of New Issues". Journal of Accounting and Economics. Vol. 8, pp159-172.

[52] Wright S, Wright AM. Information system assurance for enterprise resource planning systems: unique risk considerations. J Info Syst2002:99-115

[53] Wilkinson D. "The CICA's it competency model".
IntJAccInfoSyst 2004; 5: 245-250.

[54] Zangiabadi, M. (2014) "Factors affecting audit quality information technology", Master's thesis audit, Allameh Tabatabai University in Tehran.

[55] Zureigat, M.Q., (2011), "The Effect of Ownership Structure on Audit Quality: Evidence from Jordan" International Journal of Business and Social Science Vol. 2 No. 10; June 2011. 